\title{
Spisy archiwaliów Romana Witolda Ingardena
}

\section{SPIS NIEOGŁOSZONYCH PRAC, SZKICÓW, NOTATEK, kwiecień 1928 [maszynopis sporządzony przez Romana Witolda Ingardena]}

1. „Zagadnienie poznania u Biegańskiego”, referat na „kółku filozoficznym" we Lwowie, luty 1912 (bez wartości), stron 28;

2. „Referat na seminarium Husserla”, listopad 1913 (bez wartości), stron 22;

3. „Psychologizm w logice i fenomenologia”, odczyt w Polskim Towarzystwie Filozoficznym wygłoszony 19 XIII 1914 we Wiedniu (bez wartości), stron 34;

4. „List do Husserla o idealizmie”, lato 1918, stron 40;

5. „Idee” Husserla - zagadnienia do załatwienia, marzec 1918, stron 7;

6. Uwagi do „Idei” Husserla, 1916-18, stron 13;

7. „W sprawie tożsamości przedmiotu”, studia: Descartes, Locke, Leibniz, Hume, Reinach, nieskończone, lipiec-grudzień 1922, stron 111;

8. „O płodnej i bezpłodnej krytyce dzieł filozoficznych”, szkic artykułu, Toruń 1923, stron 10;

9. Streszczenie wykładów pt. „Wstęp do filozofii” na Studium Psychologicznym w Warszawie, wiosna 1920, stron 25;

10. Wykład wstępny do wykładów „Wstęp do filozofii”, stron 11;

11. „O jasnym i niejasnym stylu filozoficznym”, polemika z Einhornem, częściowo drukowane w Ruchu Filozoficznym, stron 35; 
12. „Ueber individuelle Zahlen-vorstellungen”, referat na seminarium J. Cohna, 1916 (bez wartości), stron 20;

13. „Rozmowa o dziele literackim”, dialog, 1918, nieskończone, stron 43;

14. Uwagi do Lotzego „Metaphysik”, materiały do pracy „O cechach względnych i bezwzględnych", 1920, stron 15;

15. Notatki z zakresu teorii sztuki, 1917, stron 18;

16. „Die Bewegung”, referat na seminarium Reinacha, bez wartości, 1914, stron 11;

17. Krytyczne uwagi do „Essai” H. Bergsona, lato 1914, stron 125;

18. Materiały do pracy o Bergsonie, niespożytkowane w tekście ogłoszonym, z r. 1914-16, stron 106;

19. „Czy i jak można poznać obiektywność spostrzeżenia zewnętrznego?" [II redakcja odczytu na Zjeździe Filozoficznym w r. 1923], niedokończona, pisana na wiosnę r. 1925, stron 36;

20. Streszczenie powyższego odczytu dla Pamiętnika Zjazdu, 1923, stron 5;

21. „O dziele literackim”, redakcja polska z wiosny r. 1925 i wiosny r. 1927, nieskończona, stron 69;

22. „Dążenia fenomenologów”, druga redakcja z jesieni r. 1926, nieskończona, stron 20;

23. „Czy i jak można wykazać obiektywność spostrzeżenia zewnętrznego", pierwsza redakcja odczytu, maj 1923, stron 27;

24. „O przyszłości nauki polskiej”, artykuł nieogłoszony, wiosna 1927, stron 12;

25. „Ueber die Gefahr einer Petitio principii in der Erkenntnistheorie”, pierwsza redakcja, częściowo ogłoszona, jesień r. 1918, stron 92;

26. „W sprawie istnienia przedmiotów idealnych”, dyskusja z T. Kotarbińskim, dodatek do „Pytań esencjalnych", nieogłoszony, wiosna 1923, stron 24;

27. „Einleitung in die Phaenomenologie”, nieskończone, jesień 1925, stron 22;

28. Pierwszy wykład z wykładów: „Niektóre kierunki współczesnej teorii poznania", jesień 1925, stron 15;

29. Notatki do wykładu: „Niektóre kierunki współczesnej teorii poznania", 1925/6, stron 82;

30. Pięć niepokończonych szkiców z dziedziny wstępu do teorii poznania z lat 1917, 1919 i 1921, stron 62;

31. „O niebezpieczeństwie petitonis principii w teorii poznania”, II redakcja z wiosny r. 1919 (nieskończone), stron 76;

32. Studia przygotowawcze do pracy o formalnej budowie przedmiotu, stron 159;

33. Notatki dotyczące zagadnienia konstytucji z r. 1915-16, stron 50;

34. Streszczenie „Pytań esencjalnych”, stron 7; 
35. „Wstęp do teorii poznania”, 1926 wiosna-jesień, nieskończone, stron 175;

36. Notatki do wykładu: „Zagadnienie obiektywności spostrzeżenia zewnętrznego", 1926/7 (nadto notatki rękopiśmienne), stron 117;

37. Początek niemieckiej redakcji: „Das Problem der Objektivität der äusseren Wahrnehmung", wiosna 1927, stron 9;

38. „Ontologie des literarischen Kunstwerks”, jesień 1927-luty 1928, stron 416.

Razem 2157 stron.

B. PRÓBY TŁUMACZEŃ

1. W. Windelband, „Podręcznik historii filozofii” (skończone), stron 284;

2. M. Scheler, „O zjawisku tragiczności” (ogłoszone), stron 49;

3. M. Scheler, "Zur Rehabilitierung der Tugend” (skończone, ale nie wykończone), stron 30;

4. M. Scheler, „Idole der Selbsterkenntnis” (nieskończone), stron 81;

5. A. Pfänder, "Einführung in die Psychologie” (nieskończone), stron 14;

6. E. Husserl, „Ideen zu einer reinen Phaenomenologie” (nieskończone), stron 7;

(wszystko pisane w Toruniu 1923-23).

Razem 465 stron.

SPIS MATERIAŁÓW REZKOPIŚMIENNYCH, MANUSKRYPTÓW NIEPUBLIKOWANYCH

ORAZ LISTÓW UCZONYCH POLSKICH

I ZAGRANICZNYCH, PISANYCH DO INGARDENA

W LATACH 1915-1940, PRZEKAZANYCH BIBLIOTECE OSSOLINEUM WE LWOWIE W 1940 ROKU

[rękopisy sporządzone przez Romana

Witolda Ingardena].

\section{Rękopisy niedrukowane}

1. „Wstęp do teorii poznania” (maszynopis, s. 1-179);

2. "Wstęp do teorii poznania" (notatki do wykładów, s. 101-236);

3. „Bemerkungen zum Problem Idealismus-Realismus” (s. 1-83, 53-105);

4. „Das literarische Kunstwerk” (s. 486-563 maszynopis, s. 355-416 rękopis); 
5. „Das Bild” (późniejsza redakcja (1939), części poz. 4, stron 47);

6. „Das Musikwerk” (maszynopis, s. 1-59);

7. „Czy i jak można poznać obiektywność spostrzeżenia zewnętrznego" (s. 1-36);

8. „Zum Problem der Identität das indiv. Gegenstand.” (maszynopis s. 74-98);

9. „Ueber die Gefahr einer Petitio principii in der Erkenntnistheorie” (maszynopis, s. 32-92);

10. Husserl „Formale und Transcendentale Logik" (s. 1-27);

11. „Zagadnienie tożsamości dzieła muzycznego” (s. 81-84, 1-26, 81$-117,89-106)$;

12. „Bemerkungen zu den «Méditations Cartésiennes»” (1-46);

13. „Wstęp do teorii poznania” (maszynopis, s. 101-175);

14. „Zagadnienie spostrzeżenia zewnętrznego" (s. 1-117);

15. Wybór wierszy z lat młodości;

16. „Wstęp do filozofii" (wykłady, stron 127);

17. „Krytycyzm Kanta” (wykłady, stron 99);

18. „Z filozofii nowożytnego Renesansu” (s. 37-58);

19. „O poznawaniu naszych stanów psych.” (odczyt, stron 26);

20. Odpisy listów Husserla.

Przejąłem dnia 15 kwietnia 1940

Inglot St[efan]

\section{Spis rękopisów prof. R. Ingardena przekazanych Bibliotece Osso- lineum we Lwowie}

1. „Pytania esencjalne” - pierwotna polska redakcja książki „Essentiale Fragen”, wraz ze „Słownikiem”, nieogłoszona drukiem z r. 1923, s. 176;

2. „Einige Voraussetzungen des Idealismus bei G. Berkeley”, niemiecka rozszerzona redakcja rozprawy zgłoszonej po polsku pod analogicznym tytułem z r. 1932, s. 85;

3. Nieznana recenzja E. Husserla z książki K. Twardowskiego, Wstęp + + tekst przyg. + tłumaczenie (z r. 1939, wysłana tuż przed wojną do red. Przegladu Filozoficznego);

4. Wypisy z E. Husserla „Zeitbewusstsein”, porównanie rękopisu w r. 1927 we Fryburgu (Rękopis Husserla został później ogłoszony!), s. 19;

5. Notatki krytyczne do E. Husserla „Londoner Vorträge”, dotychczas nieogłoszonych, z września 1927, s. 32;

6. Uwagi do Husserla artykułu o fenomenologii w „Britannica” z r. 1927;

7. „O istocie nazwy”, notatki do odczytu w Krak. Tow. Filoz.;

8. „Hauptströmungen der polnischen Philosophie”, odczyt berliński z r. 1936, s. 23;

9. „Einleitung in die Phaenomenologie”, roz. niem. niedokończona, s. 22; 
10. „Dążenia fenomenologów”, nowa red. niedokończona, s. 20;

11. Zagajenie dyskusji dot. teorii poznania, r. 1930;

12. „Czy i jak można wykazać obiektywność postrzeżenia zewnętrznego?" (Notatki do odczytu);

13. "Zagadnienie poznania u Biegańskiego", odczyt z r. 1912, s. 18;

14. „Ueber individuelle Zahlen-vorstellungen” z r. 1916, s. 20;

15. „Die Bewegung”, referat na seminarium Reinacha, z r. 1914, s. 11;

16. Odczyt w P. Tow. Filoz. we Wiedniu z r. 1914, s. 34;

17. „O płodnej i bezpłodnej krytyce dzieł filozoficznych” z r. 1923, s. 11;

18. Uwagi do „Ideen zu einer reinen Phaenomenologie” z czasów uniwersyteckich;

19. „Zweierlei Erkenntnis”, niedokończone, z r. 1918, s. 14;

20. „Contra Winawer", nieogłoszony artykuł dla Wiadomości Literackich, s. 5;

21. Uwagi do „Tragedii werbalnej metafizyki” prof. L. Chwistka, niedokończone, s. 10;

22. „Przeżycie estetyczne a poznanie dzieła sztuki”, r. 1938, s. 23;

23. „Ze studiów nad tożsamością", z r. 1922;

24. Notatki dotyczące zagadnienia "konstytucji” z r. 1915/16;

25. Różne studia przygotowawcze do pracy o formalnej budowie przedmiotu z lat 1920/22;

26. „Intensité-Nombre - krytyczne uwagi”, wiosna r. 1914;

27. Materiały do pracy o Bergsonie z lat 1914/16;

28. Szkice filozoficzne $\mathrm{z}$ lat 1918 i następnych.

Lwów, 30 IV 1940

Przejąłem Inglot St[efan]

\section{Spis rękopisów prof. Romana Ingardena przekazanych Bibliotece Ossolineum}

Następujące rękopisy przekazuję Bibliotece Ossolineum, zastrzegając sobie prawo korzystania z nich (udostępnione mogą być dopiero po mej śmierci):

1. „Prawo człowieka do kształcenia a racjonalny ustrój pracy kulturalnej", s. 9;

2. „U wrót uniwersytetu”, z r. 1933, s. 15;

3. „O przyszłość nauki polskiej” z r. 1927, s. 12;

4. List do Husserla w sprawie VI. Humanizmu i idealizmu z r. 1918, s. 41;

5. Odpowiedź na recenzję Blausteina z „Das literarische Kunstwerk” w Archiwum Psychologii z r. 1933;

6. „O dziele literackim”, pozostały rękopis z r. 1925 (Toruń), niedokończony, s. 1-57, 54-58; 
7. „Der logistische Versuch einer Neugestaltung der Philosophie”, druga rozszerzona redakcja niemiecka, która służyła za podstawę tłumaczenia francuskiego, ogłoszonego w Revue Philosophique, s. 24;

8. „Główne kierunki współczesnej teorii poznania”, notatki do wykładów na U.J.K. z r. 1934/5, s. 192;

9. „Podstawowe zagadnienia estetyki”, notatki do wykładów z r. 1938, nadto wkładki z dawniejszego wykładu, s. 48+;

10. „Niektóre poglądy współczesnej etyki”, notatki do wykładów na U.J.K. w r. 1937/8, s. 1-76, nadto z r. 1930/31, s. 1-132;

11. Młodzieńcze prace literackie proza, a mianowicie:

a) Powieść "Wędrowcy” (ostatnie dwa rozdziały wysłane do Feldmanna (krytyka) przepadły), s. 1-229;

b) „Zetlałe dusze”, fragment powieści, s. 1-88, z r. 1915;

c) Fragment powieściowy;

d) Fragment powieściowy II;

e) Tłumaczenie R. M. Rilke „Die Liebende”;

12. „Allein" - wiersze z r. 1912-13;

13. Protokoły z posiedzeń czwartkowych z 3 lat;

14. „Filozoficzne podstawy logiki”, notatki do wykładów na U.J.K. z r. 1934/40, s. 43.

Przejąłem Inglot St[efan]

\section{Listy}

Przekazuję Bibliotece Ossolineum listy następujących uczonych polskich i zagranicznych, pisane do mnie w latach 1915-1940:

A. Uczeni polscy: 1. Błachowski St. - 1; 2. Borowy Wacław - 21; 3. Gołąb Stanisław - 2; 4. Irzykowski Karol - 5; 5. Kołaczkowski Stefan - 32; 6. Kotarbiński Tadeusz - 30; 7. Kridl Manfred - 5; 8. Krzemicka Irena 21; 9. Krzyżanowski Julian - 1; 10. Łempicki Zygmunt - 25; 11. Michalski K. - 13; 12. Nałkowska Zofia - 1; 13. Pietruskiewicz - 3; 14. Rosenblum A. - 18; 15. Sobeski Marian - 3; 16. Szuman Stefan - 23; 17. Tatarkiewicz Władysław - 15; 18. Treter M. - 2; 19. Twardowski Kazimierz - 39; 20. Wallis-Walfisz Mieczysław - 2; 21. Witkiewicz Stanisław Ignacy - 86; 22. Witwicki Władysław - 105.

Razem 453 strony (korespondencja ta zawiera liczne luki, wiele listów zniszczyłem w grudniu 1939 r.).

B. Uczeni zagraniczni: 1. Baudin (Francja) - 1; 2. Bayer R. (Francja) - 5; 3. Beck M. (Niemcy) - 1; 4. Becker O. (Niemcy) - 8; 5. Bréhier E. (Francja) -3 ; 6. Brøndal V. (Dania) - 1; 7. Bühler K. (Austria) - 1; 8. Claus 
L. F. (Niemcy) - 17; 9. Cornelius H. (Niemcy) - 11; 10. Dessoir M. (Niemcy) - 3; 11. Elbracht-Hülseweh (Niemcy) - 2; 12. Focillon H. (Francja) 1; 13. Gaertner (Węgry) - 1; 14. Geiger M (Niemcy) - 3; 15. Gurvitch G. (Francja) - 1; 16. Hankiss J. (Węgry) - 1; 17. Hannay (Anglia) - 1; 18. Hering Jean (Francja) - 19; 19. Hartmann N. (Niemcy) - 2; 20. Hefman P. (Niemcy) - 1; 21. Husserl M. (Niemcy) - 13. Uprzednio oddałem Ossolineum odpisy około 100 listów E. Husserla; 22. Jaensch E. R. (Niemcy) 2; 23. Kamiat (USA) - 1; 24. Katikow G. (Czechosłowacja) - 4; 25. Kaufmann Felix (Austria) - 11; 26. Kaufmann Fritz (Niemcy) - 2; 27. Koyré Al. (Francja) - 15; 28. Kozák (Czechosłowacja) - 1; 29. Kuhn H. (Niemcy) - 4; 30. Lalo Ch. (Francja) - 1; 31. Kramer-Kreissl (Niemcy) - 1; 32. Landgrebe L. (Niemcy) - 2; 33. Leo H. (Niemcy) - 1; 34. Leon Ph. (Anglia) - 7; 35. Liebert (Niemcy-Jugosławia) - 9; 36. Lipps Hans (Niemcy) - 2; 37. Mágr St. (Czechosłowacja) - 3; 38. Moore G. E. (Anglia) - 1; 39. Niemeyer M. (Niemcy) - 7; 40. Patsch R. (Niemcy) - 1; 41. Pfänder Al. (Niemcy) $-12 ; 42$. Ploetz (Niemcy) - 1; 43. Reich O. (Czechosłowacja) - 1; 44. Robin (Francja) - 1; 45. Scheler M. (Niemcy) - 1; 46. Scholz H. (Niemcy) - 1; 47. Sobry P. (Belgia) - 1; 48. Spiegelberg H. (Niemcy) - 5; 49. Spranger E. (Niemcy) - 2; 50. Stein E. (Niemcy) - 162; 51. Tschižewskyj D. (Niemcy)-2; 52. Utitz E. (Niemcy-Czechy) - 4; 53. Walther G. (Niemcy) - 21. Razem 389 listów.

Ogółem listów 842. Listy te mogą być udostępniane dla celów naukowych dopiero $\mathrm{w}$ jakiś czas po mojej śmierci

Lwów, 3 V 1940 r.

prof. Roman Ingarden Przejąłem Inglot St[efan]

\section{Oświaczenie dotyczące przekazania „Poetyki” do Biblioteki Ossoli- neum}

Przekazuję Bibliotece Ossolineum - z prośbą o dołączenie do poprzednio wręczonych rękopisów - rękopis „,Poetyki” (I i II rozdz.).

23. V. 42

Roman Ingarden

Otrzymałem Inglot St[efan] 


\section{Oświadczenie dotyczące przekazania kolejnych rękopisów do Biblio- teki Ossolineum}

Przekazałem Bibliotece Ossolineum dodatkowo - z prośbą o dołączenie do poprzednio przekazanego zbioru rękopisów.

1. „O poznawaniu autora dzieła sztuki”, str. 1-15 (r. 1939 - niedokończone);

2. „Problematyka sprawy autor-dzieło”, str. 1-5 (1939 - niedokończone);

3. „O sądzie warunkowym”, str. 1-11 (maszyna) + str. 1-3(I-II)-11 (rękopis) - (1936) niedokończone;

4. Notatki do odczytu "Zagadnienie budowy sądu warunkowego" (str. $1-9)$;

5. „O poznawaniu autora dzieła sztuki przy pomocy jego dzieła” (notatki do odczytu, 39, str. 1-8);

6. Zagajenie dyskusji "Zagadnienie akcentów wyrażających autora w dziele sztuki" (39), str. 1-4;

7. „Bemerkungen zu Lessings «Laokoon»” (notatki do odczytu, str. 1-5) (alegat - wyjęty z „Laokoona”);

We Lwowie, 16. VII. 1943

R. Ingarden

Otrzymałem

Mańkowski

Spis maszynopisów (rękopis sporządzony przez Ingardena, częściowy)

Szafa lewa

A. Od lewej pierwszy stos od dołu (od lewej)

1. „Das literarische Kunstwerk” - dawna redakcja, część, rękopis paryski;

2. „Spór" po niemiecku, część najdawniejszej redakcji, zmiany późniejsze, braki, chaos;

3. „Spór" po polsku od 596-1089 (z poprawkami, tekst wojenny);

4. "Streit", tom I, redakcja ostateczna, egzemplarz, z którego drukowano;

5. „Streit”, tom II/1, redakcja ostateczna, egzemplarz, z którego drukowano;

6. „Streit”, tom II/2, redakcja ostateczna, egzemplarz, z którego drukowano;

7. „Streit”, tom II/2, ostateczna redakcja, oryginał;

8. „Streit”, tom II/2, ostateczna redakcja, kopia (6); 
9. „Spór", III tom po niemiecku, materialna ontologia, 1-31. str. + inna redakcja i spis paragrafów;

9a. „Beiträge zum Problem Idealismus-Realismus”.

B. Drugi stos od dołu (środek)

10. „O pytaniach esencjalnych”, pierwotny oryginał, 1-176 str.;

11. „O pytaniach esencjalnych”, odpis (10);

12. „O pytaniach esencjalnych”, odpis (10) i przypisy;

13. „Form, Inhalt und Wert des literarischen Kunstwerks”, nieskończony, pisany we Lwowie 1940/41, 1-94 str.;

14. „Das Kausalproblem”, oryginał z r. 1950-54;

15. „Przyczynowość”, wykłady, magnetofonowy + notatki 1962/3;

16. „Przyczynowość”, wykłady, kopia (15);

17. Wykłady: „Wstęp do filozofii”, ,Główne kierunki współczesnej filozofii”, ,Brentano” (notatki), „Filozofia XX w." (3-5) magnet.;

18. Wykłady z etyki U.J.K., 1935, U.J., notatki do wykładów, częściowo przepisane na maszynie;

19. Odczyty: 1. w Royaumont, 2. Fribourg, 3. w Brooklyn, 4. w San Francisco (po niemiecku i po angielsku), 5. „Zasady krytyki poznawczej doświadczenia estetycznego", magnetofon, PTF, 6. Leiden, „Wartości est." - odczyt, 7. Eduk.;

20. Notatki do odczytów;

21. Wykłady z estetyki U.J., magnetofon 1960;

21a. II egzemplarz;

22. Wykłady z historii filozofii nowożytnej, Lwów U.J.K., fragment.

C. Trzeci stos, od dołu, od prawej

23. Tłumaczenie francuskie I tomu „Sporu”, Kołodziej 1959;

24. Tłumaczenie francuskie: „Architektura” (Dąmbska), „,Obraz” (Gromska);

25. Konwersatorium o czasie 1947/48, protokoły posiedzeń; Seminarium protokoły 1946/47, metodologia nauk;

25. Konwersatorium estetyczne 1945/46 - protokoły;

26. Notatki z dzieł czytanych w Paryżu 1956;

Teksty angielskie odczytów w USA, 1959/60:

1. „Relativity of value”, później czytany w Leeds;

2. "The formal essence of the relation” (Madison 1959);

3. „Typy cech - absol. i wzgl.";

4. ad Findlay, Oxford 1964 [sic!];

27. Polska terminologia filozoficzna - Kant;

28. „O tłumaczeniach”, odpis, drukowane;

29. Pamiątki ze zjazdów: Alpbach, Royaumont;

30. Notatki, wypisy: Lewis, Łukasiewicz i wiele innych; 
31. Wykłady, notatki, magnetofon: „Filozofia XX wieku”, U.J. 1961/62;

32. Różne:

1. Recenzja z pracy Hanneborga;

2. „Ze studiów nad zagadnieniem formy i treści dzieła sztuki” (odpis);

3. „Das Form-Inhalt-Problem” (odpis), drukow.;

4. „O twórczości kompozytora i współtwórczości wirtuoza i publiczności";

5. „Artistic values and aesthetic values" (Makota);

6. „On systematisation of aesthetically valuable qualities” (Makota);

7. „Künstlerische und aesthetische Werte” (Leyden [sic!]);

8. „Z rozważań nad wartościami moralnymi” (dla Czeż.);

9. Alpbach;

10. Recenzja rozprawy P. Graffa;

11. „Teoria literatury artystycznej (Poetyka)”, Lwów 1941;

12. List do Spiegelberga;

13. „Problematyka sprawy autor-dzieło”, rękopis 1937/8;

14. „O poznawaniu autora dzieła sztuki”, maszyn., rok 1938;

15. „O poznawaniu cudzych stanów psych.”, 1939, odczyt;

33. „Etyka”, wykłady U.J. 1961/62 - magnetofon, drugi egz.;

34. Wykłady z etyki 1961/62, poprawione kilka początków;

35. „Estetyka”, wykłady U.J., 1960/61, magnetofon;

36. Różne:

1. „O dziele literackim”, Toruń 1922, str. 54;

2. „Wartości estetyczne i zagadnienie ich ugruntowania w przedmiocie", notatki do odczytu PTF;

3. „O ocenie estet.”, Torun 1953? Tow. Naukowe;

4. „Film” po francusku, 1947 (drukowane);

5. Oslo, wykłady z estetyki, 1967, notatki;

37. „Über den Gegenstand und die Aufgaben der Literaturforschung” zaczęte 1968;

Prawa szafa

A.

38. Notatki dotyczące zagadnienia konstytucji, Getynga 1915, rękopis;

„O niebezpieczeństwie petitio principii w teorii poznania”, 1919, Lublin 1919, rękopis;

39. „Ueber die Gefahr einer Petitio principii”, oryginał, Lublin 1918, 92;

2 odpisy części II i III „Ueber die Gefahr einer Petitio principii”;

40. „Zagadnienie obiektywności spostrzeżenia zewnętrznego”, wykłady U.J.K. 1926/7, notatki, odpisy dwa;

40a. To samo - oryginał lwowski U.J.K.;

41. „Wstęp do teorii poznania” (najdalej posunięta redakcja, częściowo podwójny tekst); 
42. „Wstęp do teorii poznania”, dawne redakcje:
a) 1932, stron 1-102;
b) 1938, stron 1-93;

43. „Wstęp do teorii poznania":

III redakcja (1938), stron 114;

IV redakcja (1947), stron 117;

44. „Czy i jak można wykazać objektywność spostrzeżenia zewnętrznego" (Toruń 1921-Toruń 1924/5?);

„Das Problem der Objektivität der äusseren Wahrnehmung";

"O spostrzeżeniu" (Rabka 1949?);

45. „Objektivität” (1966/7);

46. „Einige Voraussetzungen des Idealismus bei Berkeley”, oryginał + +2 odpisy;

47. „Krytycyzm Kanta”, wykłady, 1935 (notatki + opracowanie);

48. Stare rękopisy:

1. Pięć fragmentów z teorii poznania 1918-21;

2. „Wstęp do teorii poznania”, wykład U.J.K. 1925/26, notatki;

3. „Najwybitniejsze kierunki współczesnej teorii poznania”, wykład U.J.K., 1925/26 (notatki);

4. Różne drobne;

49. $\alpha$ ) „Poglądy epistemologiczne H. Helmholtza”, 1-59, 2 egzemplarze (pierwszy z poprawkami);

乃) „Pozytywizm”;

50. „Metodologia”, wykłady w U.J. 1948/49 (red. D. Gierulanka), brak pierwszych czterech wykł., tylko w notatkach;

51. „O roli sądów”, po polsku i część po niemiecku;

52. „Das hypothetische Urteil”;

53. „Logistyczna próba nowego ukształtowania filozofii” (tłumaczenie z francuskiego, dany tekst polski), czy drukowane?;

54. Różne:

1. „Uwagi o uzasadnieniu sądów” (Jabłonna);

2. „Kritische Betrachtungen zur Phonologie”;

3. "Krytyczne uwagi o poglądach fonologów”, PAU, dwa odpisy (drukowane);

4. "Człowiek i przyroda";

5. „O naturze ludzkiej”;

6. Część odczytu o konstytucji przedmiotu fizykalnego, PTF, magnetofon;

7. Notatki do odczytu w Wiedniu (,Zeitperspektiven...”);

8. Notatki do odczytu „Vom Erkennen” (1964);

9. „O słowie jako składniku określonego języka”, odczyt Oxford;

10. „Ogólna anatomia dzieła sztuki”, Sekcji Estetyki, '63;

11. „Zagadnienie tożsamości dzieła muzycznego”, odczyt Szkoła Muzyczna ('67); 
12. „Niektóre twierdzenia o związku przyczynowym”, PTF, 1954 (notatki);

55. Różne:

1. Odczyt o E. Stein, notatki;

2. „Kausalproblem” - dla Merlana;

3. „Was gibt es neues in der «Krisis»?", Waterloo, '69;

56. „Ontische Fundamente der Verantwortung”, 1968/9;

57. 1. Listy do Husserla - rękopisy i odpisy;

2. Recenzja z „Logiki” Husserla;

3. Wypisy z Husserla;

4. „Bemerkungen zu den «Kartesianischen Meditationen»”, 1930;

58. Notatki do odczytu w USA, Minneapolis;

59. Husserl, odczyty o Husserlu, Recenzja „Logik”, artykuł do „Encyklop.", wypisy;

60. Różne:

1. „Der aesthetische Wert und das Problem seiner gegendständlichen Fundierung", tekst dla Utitza, 1956, Wenecja;

2. „Wisła musi być uregulowana”, 1945;

3. „Odpowiedź Blausteinowi” (niedrukowane, Baley odmówił!);

4. „Na marginesie rozprawy Schrödingera «What is Life?»", niedrukowane („Problemy”);

5. „Prawo człowieka do kształcenia się a racjonalny ustrój pracy kulturalnej" (niedrukowany);

6. Propozycje zmian w tekście III tomu „Historii Filozofii” Tatarkiewicza;

7. „Marginalia Mickiewicza do «Etyki» Spinozy” (na zaproszenie Komitetu, nie usłuchali);

8. „Poetyka a językoznawstwo” (1960, Warszawa);

9. „Résumé d'intervention 20. VIII 1960, ad M. Davie”;

10. „Niektóre zagadnienia dotyczące związku przyczynowego”;

11. „O słowie jako składniku określonego języka”, PAU, 1949, notatki;

12. W odpowiedzi na zarzuty J. Krzyżanowskiego („Nowa Książka”, przed wojną!);

13. „Hauptströmungen der polnischen Philosophie”, 1936;

14. „U wrót uniwersytetu”, (1937);

15. List do Żółkiewskiego (1967);

16. Odczyt wiedeński, 1968, estetyka;

17. Odczyt w Belgradzie o wartościach, 1965;

18. „La conception de la philosophie chez Brentano”;

19. "Aporien des Kausalzusammenhanges", notatki do odczytu w Tow. Filoz., Fribourg, '57;

1 W pierwotnej dacie „1966" ostatnią cyfrę poprawiono na ",7". 
20. „Das Problem der gegenständlichen Fundierung der aesthetischen Werte", Fribourg, 1957, notatki;

21. „O dyskusji owocnej słów kilka”, druk., 1961;

22. "L'Homme et la Nature” (maszynopis - drukowane);

23. Estetyka, różne określenia - (?);

24. Recenzja "Stylistyki teoretycznej w Polsce" Budzyka ('47);

25. Notatki do odczytu o „Bense - metody statystyczne”;

26. Wypisy z Condillaca;

27. „Czego nie wiemy o wartościach?”, notatki, PTF 1964;

61. Różne: Maszynopis artykułu o Husserlu dla encyklopedii.

[Dalej podane zostaje zestawienie odczytów ( $z$ wymienionymi latami i liczba, od 1945 roku do 1964 - 85 odczytów, 38 zagranicznych) oraz spis kongresów $z$ podaniem daty. Te dwie listy pomijamy.]

\section{Spis manuskryptów (maszynopis sporządzony przez Ingardena)}

Szafa prawa - środek (B II) od góry

I. Husserl - odpisy listów (Lwów) i manuskryptów (Louvain) + recenzja Husserla o Twardowskim, oryginał plus tłumaczenie moje;

II. „Z rozważań nad wartościami moralnymi”"2 do Księgi dla Czeżowskiego;

III. Odczyt o Husserlu w Göttingen (notatki), 1958;

IV. Alpbach, protokoły posiedzeń (dostarczone przez biuro);

V. Recenzja z rozprawy doktorskiej Graffa;

VI. List do Spiegelberga (Lwów), oryginał, w odpowiedzi na jego artykut;

VII. „Teoria literatury (Poetyka)”, rękopis z r. 1941, Lwów, stron 44;

VIII. „O tłumaczeniach”, odpis tekstu drukowanego;

IX. „O twórczości kompozytora, wirtuoza i publiczności”, BUMA, polskie tłumaczenie, Amsterdam 1964;

X. „Artistic values and aesthetic valuable qualities” (tekst odczytu w Londynie i Manchesterze), tłum. Makoty;

XI. „On systematisation of aesthetic valuable qualities” (tekst odczytu w Manchester), tłum. Makoty;

XII. Odczyt w Leuven, grudzień 1963(?);

XIII. „O wychowywaniu uczonych”, maszynopis drukowany;

XIV. "Człowiek i przyroda” (tłum. odczytu w Wenecji);

XV. „O naturze ludzkiej”, tłum. odczytu w Montpellier;

XVI. „Czego nie wiemy o wartościach”, notatki do odczytu PTF;

${ }^{2} \mathrm{Na}$ jednym $\mathrm{z}$ dwóch egzemplarzy tego spisu Ingarden dopisał odręcznie: ,+ fotokopie Finka". 
XVII. „O konstytucji przedmiotu fizykalnego u Husserla”, PTF, część, magnetofon;

XVIII. „Zeitperspektiven...” (notatki do odczytu w Wiedniu, 1964);

XIX. „Vom Erkennen des literar. Kunstwerks”, notatki do odczytu w Wiedniu, 1964;

XX. „O słowie jako składniku określonego języka”, tłum. odczytu w Oxford;

XXI. Sekcja estetyki, notatki do odczytów, 1963;

XXII. „Niektóre twierdzenia o związku przyczynowym”, notatki do odczytu PTF, 1954;

XXIII. Notatki do odczytu w Wyższej Szkole Muzycznej, Warszawa;

XXIV. „Das hypothetische Urteil” (1956), tekst posłany do Kaufmanna, częściowo drukowany po angielsku w jego tłumaczeniu;

XXV. O Husserlu dla „Słownika Filozofów”;

XXVI. Recenzja z pracy Półtawskiego;

XXVII. Magnetofonowe zapisy mego udziału w dyskusjach w zjeździe we Fribourgu;

XXVIII. Wypisy z Twardowskiego (dla odczytu);

XXIX. „Das Problem der Systems der aesthetisch valenten Qualitäten”;

XXX. Wykłady z etyki U.J., magnetofon;

XXXI. Wykłady z etyki U.J., kilka, poprawiony z magnetofonu;

XXXII. „Berkeley” po niemiecku, oryg. i odpisy (nie drukowane);

XXXIII. Teksty i odpisy do „Kleine Schriften zur Aesthetik”;

XXXIV. „Betrachtungen zum Problem der Objektivität” (drukowane) $\mathrm{i}$ „O różnych rozumieniach obiektywności”, notatki do odczytu w PTF;

XXXV. List do Husserla (po niemiecku, oryginał 1918) i odpis na maszynie;

XXXVI. „O dyskusji owocnej słów kilka”, druk;

XXXVII. Fotokopie maszynopisów Finka dla Husserla, 25.I.69

XXXVII. Teczka Amsterdamska, odczyty 1969;

XXXVIII. Teczka Wiedeńska, odczyty na kongresie;

XXXIX. „Ontische Fundamente der Verantwortung”, ostateczna redakcja;

XL. Teczka sztywna brązowa:

1. „E. Stein”;

2. Odpis dla Merlana;

3. „Was gibt es Neues in Husserls Krisis?” - oryginał i odpis ostatecznej redakcji;

4. „Bericht über meine Studien zur Ästhetik”3.

3 Pozycje zapisane po dacie „25.I.69” w jednym z egzemplarzy spisu są dopisane odręcznie przez Ingardena, w drugim dopisane na maszynie. 


\section{Spis maszynopisów [sporządzony z maszynopisu Ingardena, nieznanego nam, a przepisanego przez Danutę Gierulankę do poz. 79 ; dalej dodane $w$ tym spisie pozycje do numeru 86$]^{*}$}

Spis maszynopisów

1. „Das literarische Kunstwerk” - dawna redakcja, część rękopisu parysk., początek redakcji polskiej z 1922 i 1927 r.;

2. „Spór" po niemiecku, część najdawniejszej redakcji, zmiany późniejsze, braki, chaos;

3. „Spór" po polsku od str. 594-1089 (z poprawkami, tekst wojenny);

4. „Streit”, tom I, red. ostatnia, egzemplarz, który drukowano;

5. „Streit”, tom II/1, red. ostatnia, egzemplarz, który drukowano;

6. "Streit”, tom II/2, red. ostateczna, egzemplarz, który drukowano;

7. "Streit", tom II/2, ostateczna redakcja, oryginał;

8. "Streit”, tom II/2, ostateczna redakcja, kopia (6);

9. "Spór", III tom po niemiecku, materialna ontologia, 1-31. str. + inne redakcje i spis paragrafów;

9a. „Beiträge zum Problem Idealismus-Realismus”;

10. „O pytaniach esencjalnych”, pierwotny oryginał, s. 1-176 z r. 1923;

11. „O pytaniach esencjalnych", odpis (10);

12. "O pytaniach esencjalnych”, odpis (10) i przypisy;

13. „Form, Inhalt und Wert des literarischen Kunstwerks”, s. 1-94, nieskończony, pisany we Lwowie 1940-1941;

14. „Das Kausalproblem”, oryginał z r. 1950-54, drugi egzemplarz znajduje się w Tübingen na przechowaniu u Niemeyera, widziałem go w r. 1969;

15. „Przyczynowość”, wykłady U.J., magnetofonowy odpis i notatki do wykładów w r. 1962/63;

16. „Przyczynowość", wykłady, kopia (15);

17. Wykłady: „Wstęp do filozofii”, ,Główne kierunki współczesnej filozofii”, „Fr. Brentano" (notatki), „Filozofia XX w.” (3-5) magnet.;

18. Wykłady z etyki w U.J.K., 1935, potem w U.J., notatki do wykł., częściowo przepisane na maszynie;

19. Odczyty: 1. w Royaumont, 2. Fribourg, 3. w Brooklyn, 4. w San Francisco (po niem. i po ang.), 5. „Zasady krytyki poznawczej doświadczenia estetycznego", magnetofon, PTF;

20. Notatki do odczytów;

* W Archiwum Nauki PAN i PAU znajduje się kopia (maszynopis) spisu pt. „Spis maszynopisów i ich rozmieszczenie w szafach", obejmująca 90 pozycji, stanowiąca podstawę do przekazywanych sukcesywnie od 1972 r. materiałów R. Ingardena do działu spuścizn. Spis ten pokrywa się z powyższym zestawieniem. Bardzo dziękujemy Pani Dr Ricie Majkowskiej za powyższą informację. 
21. Wykłady z estetyki U.J., magnetofon 1960;

21a. Wykłady z estetyki U.J., drugi egzemplarz (21);

22. Wykłady z historii filozofii nowożytnej, U.J.K., Lwów, fragment;

23. Tłumaczenie francuskie I tomu "Sporu”, Kołodziej, 1959;

24. Tłumaczenie francuskie: „Dzieło architektury” (Dąmbska), „O budowie obrazu" (Gromska);

25. Konwersatorium o czasie 1947/48, protokoły posiedzeń;

Seminarium z metodologii nauk 1946/47, protokoły posiedzeń (? 1948/49 D. G.);

25. Konwersatorium estetyczne 1945/46, protokoły posiedzeń;

26. Notatki z dzieł czytanych w Paryżu 1956;

Teksty angielskie odczytów w USA, 1959/60:

1. „Relativity of values”, czytany potem w Leeds;

2. "The formal essence of the relations" (Madison 1959);

3. "O typach cech absolutnych i względnych";

4. Uwagi krytyczne ad Findlay, Oxford 1964;

27. Polska terminologia filozoficzna do Kanta (fragment);

28. „O tłumaczeniach”, odpis tekstu drukowanego;

29. Różne notatki ze zjazdów: Alpbach, Royaumont 1957;

30. Notatki, wypisy: Lewis, Łukasiewicz i wiele innych;

31. Wykłady: „Filozofia XX wieku”, notatki, magnetofon, U.J. 1961/1962, fragm.;

32. Różne:

1. Recenzja rozprawy Hannoberga;

2. "Ze studiów na zagadnieniem formy i treści dzieła sztuki”, odpis tekstu drukowany w Przegladzie Filozoficznym;

3. „Das Form-Inhalt Problem im literarischen Kunstwerk”, odpis tekstu drukowanego;

4. „O twórczości kompozytora i współtwórczości wirtuoza i publiczności" (tłum. moje artykułu niem., BUMA Amsterdam 1964);

5. "Artistic values and aesthetic values" (tłum. Makoty, niedrukowane);

6. „On systematisation of aesthetically valuable qualities”, tłum. Makoty, tekst odczytu w Manchester (1963);

7. „Künstlerische und aesthetische Werte”, tekst odczytu w Leyden [sic!] 1953;

8. „Z rozważań nad wartościami moralnymi”, magnet. wykł. U.J., do księgi pamiątkowej dla Czeżowskiego;

9. Rożne notatki w Alpbach;

10. Recenzja rozprawy doktorskiej Graffa;

11. „Teoria literatury artystycznej (Poetyka)”, Lwów 1941;

12. List do Spiegelberga (odpowiedź na jego recenzję), 1932;

13. „Problematyka sprawy autor-dzieło”, rękopis 1937/8, fragment;

14. „O poznawaniu autora dzieła sztuki”, maszynopis 1938; 
15. „O poznawaniu cudzych stanów psychicznych”, odczyt w Lwowskim Towarzystwie Naukowym, Walne Zebranie, 1939 czerwiec, Lwów;

33. „Etyka”, wykłady w U.J. 1961/62 - magnetofon, drugi egzemplarz;

34. Wykłady z etyki 1961/62, poprawiony (kilka początk. w.);

35. „Estetyka”, wykłady w U.J., 1961/62, magnetofon;

36. Różne:

1. „O dziele literackim”, początkowa red., Toruń 1922, s. 54 (p. 1 $\left.\mathrm{DG}^{4}\right)$;

2. „Wartości estetyczne i zagadnienie ich ugruntowania w przedmiocie", notatki do odczytu w PTF;

3. „O ocenie estetycznej”, Torun 1952, odczyt w Towarzystwie Naukowym;

4. „Kilka uwag o filmie”, tekst franc. posłany do Paryża, tam drukowany;

5. Notatki do wykł. estetyki w Oslo, 1967;

37. „Über den Gegenstand und die Aufgaben der Literaturwissenschaft”, fragment 1968;

38. Notatki dotyczące zagadnienia konstytucji, Getynga 1915, rękopis; „O niebezpieczeństwie petitionis principii w teorii poznania”, fragment polskiej redakcji z r. 1918/19 w Lublinie 1919, rękopis;

39. „Ueber die Gefahr einer Petitio Principii in der Erkenntnistheorie”, oryginał, Lublin 1918/19, częściowo drukowany w "Jhrb." IV, s. 92;

Dwa odpisy części II i III (39) dotąd nie ogłoszonych;

40. „Zagadnienie obiektywności spostrzeżenia zewnętrznego”, notatki do wykł. w U.J.K., Lwów, 1926/7, oryginał lwowski;

40a. Dwa odpisy (40);

41. „Wstęp do teorii poznania” (najpóźniejsza, najdalej posunięta redakcja, maszynopis, częściowo podwójny tekst);

42. „Wstęp do teorii poznania”, dawne redakcje: a) 1932, s. 1-103, b) 1938, s. 1-93, notatki z literatury z Zürichu 1938;

43. „Wstęp do teorii poznania": III redakcja 1938, s. 1-114;

IV redakcja 1947, stron 47;

44. „Czy i jak można wykazać obiektywność spostrzeżenia zewnętrznego", tekst odczytu na I Zjeździe Filoz. Pol., Lwów 1923, pisane Toruń 1922, fragment;

„Das Problem der Objektivität der äusseren Wahrnehmung”;

"O spostrzeżeniu, fragment", Rabka 1949?;

45. „Betrachtungen zum Problem der Objektivität” 1956/57, potem drukowane w Zeischrift für philosophische Forschung, 1967;

46. „Einige Vorausdetzungen des Idealismus bei Berkeley”, niemiecka redakcja z r. 1931, nie ogłoszona, dwa odpisy;

\footnotetext{
${ }^{4}$ Tekst w nawiasie wpisany odręcznie przez Danutę Gierulankę.
} 
47. „Krytycyzm Kanta”, wykłady w U.J.K. Lwów 1935, notatki do wykładów przepisane przez Jurka, cz. druga w opracowaniu Krońskiej i Bednarowskiego;

48. Stare rękopisy:

1. Pięć fragmentów z teorii poznania 1918-25?;

2. „Wstęp do teorii poznania”, wykład na U.J.K. 1925/26, notatki;

3. „Najwybitniejsze kierunki współczesnej teorii poznania”, wykład w U.J.K. 1926(?), notatki;

49. „Poglądy epistemologiczne H. Helmholtza”, str. 1-59, dwa egzemplarze, pierwszy z poprawkami;

50. „Metodologia”, wykłady w U.J. 1948/49, opracowanie D. Gierulanki, brak pierwszych 4 wykładów, które są tylko w moich notatkach;

51. „O roli sądów w poznawaniu”, po polsku 1950/51, część po niemiecku (po roku 1960);

52. „Das hypothetische Urteil”, red. niem. wysłana do Farbera, przełożona na jęz. ang. przez Fr. Kaufmanna, ogłoszona część w czasop. Philosophy and Phenomenological Research;

53. „Logistyczna próba nowego ukształtowania filozofii” (tłumaczenie $\mathrm{z}$ francuskiego);

54. Różne:

1. „Uwagi o uzasadnieniu sądów”, (tekst odczytu w Jabłonnie), ogłoszone w red. niem, w Studia Logica;

2. „Kritische Betrachtungen zur Phonologie";

3. „Krytyczne uwagi o poglądach fonologów”, PAU, dwa odpisy drukowane w Sprawozdaniach z Posiedzeń PAU;

4. „Człowiek i przyroda”, tłumaczenie moje odczytu fr. w Wenecji 1958;

5. „O naturze ludzkiej”, tłumaczenie moje odczytu franc. w Montpellier, drukowane w Polsce;

6. Część odczytu o konstytucji przedmiotu fizykalnego, PTF, magnetofon;

7. Notatki do odczytów w Wiedniu 1964: Zeitperspektive;

8. Notatki do odczytów w Wiedniu 1964: Vom Erkennen;

9. „O słowie jako składniku określonego języka”, odczyt, Oxford;

10. „Ogólna anatomia dzieła sztuki”, dys. odcz. w Sekcji Estetycznej;

11. „Zagadnienie tożsamości dzieła muzycznego” (Szk. Muz. 57);

12. "Niektóre twierdzenia o związku przyczynowym”, notatki do odczytu w PTF 1954;

55. Różne:

1. Odczyt o Edith Stein, u Kardynała Wojtyły 1968, notatki;

2. „Kausalproblem”, artykuł dla Merlana (I. rozdz. D. Kausal);

3. „Was gibt es neues in der «Krisis» Husserls”, odczyt w Waterloo, tekst niemiecki i angielski; 
4. „Co nowego w ostatniej książce Husserla” (dla Studiów Filozoficznych);

5. „Bericht über meine Studien zur Aesthetik”;

56. „Ontische Fundamente der Vorantwortung”, tekst do druku, 1958;

57. Różne:

1. Listy do Husserla, rękopisy i odpisy;

2. Recenzja $\mathrm{z}$ „Logik" Husserla, po niemiecku, pełny tekst;

3. Wypisy z Husserla, głównie „Krisis”;

4. „Kritische Bemerkungen zu den «Cartesianischen Meditationen»", oryginał 1930, częściowo drukowane;

58. Notatki do odczytu w Minneapolis;

59. Husserl, odczyty o Husserlu, Recenzje z „Logiki”, artykuł dla „Słownika Filozofii", wypisy z Husserla;

60. Różne:

1. „Der aesthetische Wert und das Problem seiner gegendständlichen Fundierung", dla Utitza, Wenecja 1958;

2. „Wisła musi być uregulowana”, artykuł dla Tygodnika odrzucony;

3. „Odpowiedź Blausteinowi”, niedrukowane, Baley odmówił;

4. „Na marginesie rozprawy Schrödingera «What is Life?»", artykuł dla Problemów, niedrukowany;

5. „Prawo człowieka do kształcenia się a racjonalny ustrój pracy kulturalnej" (do Wiadomości, ale nie posłałem), 1936;

6. Propozycja zmian w tekście III tomu „Historii” Tatarkiewicza; prosił, ale nie uwzględnił;

7. „Marginalia Mickiewicza do «Etyki» Spinozy” (na życzenie Komitetu wydającego Dzieła Mickiewicza - rady nie usłuchali);

8. „Poetyka a językoznawstwo”, tekst polski niemieckiego referatu na Międzynarodowej Konferencji Poetyki, W-wa 1960;

9. „Résumé d'une intervention a M. Davis”, 20.8.1960;

10. „Niektóre zagadnienia dotyczące związku przyczynowego”;

11. „O słowie jako składniku określonego języka”, notatki do odczytu w Komisji Językowej PAU, 1949;

12. „Hauptströmungen der polnischen Philosophie”, odczyt w Berlinie 1960;

13. „U wrót uniwersytetu”, odczyt dla maturzystów 1936;

14. List do Żółkiewskiego;

15. Odczyt na Kongresie we Wiedniu o estetyce, 1968(?);

16. Odczyt w Belgradzie: „Czego nie wiemy o wartościach?”, notatki 1965;

17. „La conception de la philosophie chez Franz Brentano”, tłum. francuskie części artykułu polskiego, posłane do druku do Archives de Philosophie;

18. „Aporien des Kausalzusammenhanges”, notatki do odczytu we Fryburgu Szwajcarskim, 1956, Towarzystwo Filozoficzne; 
19. „Das Problem der Gegenständlichen Fundierung der aesthetischen Werte", Fribourg, Université, 1957, notatki;

20. „O dyskusji owocnej słów kilka”, drukowane w Przegladzie Kulturalnym;

21. „L'homme et la nature”, Kongres w Wenecji, drukowane 1958;

22. Rożne określenia, notatki;

23. W odpowiedzi J. Krzyżanowskiego, drukowane;

24. Recenzja ze „Stylistyki teoretycznej w Polsce” Budzyka (na żądanie Ministerstwa, 1957);

25. Notatki do odczytu o M. Bense i metodach statystycznych, PAN, Instytut Sztuki, 1967;

26. Wypisy z Condillaca;

27. „Czego nie wiemy o wartościach?”, notatki do odczytu PTF 1964; 61. Różne:

1. Maszynopis artykułu o Husserlu dla „Encyklopedii";

2. Recenzja pracy Półtawskiego dla PWN;

3. Magnetofonowy zapis odczytu we Fryburgu i dyskusji (po francusku);

4. Artykuł „A. Koyré” dla „Słownika Filozofów”;

5. Wypisy z Twardowskiego - do odczytu;

62. Husserl, Listy - odpisy z rękopisów Husserla w Louvain, Recenzja z książki Twardowskiego;

63. Różne:

1. Część odczytu we Fribourg: Konstyt. i przed. fiz. u H., po niemiecku;

2. „O estetyce”, Wiedeń 1968;

3. „O estetyce”, Wiedeń 1968, po niemiecku i poprawiona redakcja do druku;

4. „Max Bense”, po niemiecku, niepoprawione;

5. To samo (4) poprawione, posłane do druku (w odpisie);

6. „O twórczości kompozytora i współtwórczości wirtuoza”, moje tłumaczenie, drugi egzemplarz;

7. „Funkcje artystyczne języka” (tekst ostateczny) do druku;

8. „M. Bense i metody statystyczne”, po polsku, tekst rozszerzony do druku;

9. „Nachwort” do „Erlebnis, Kunstwerk und Wert”, pierwsza redakcja, wycofana;

10. Drugie wydanie Encyklopedii włoskiej - do druku;

11. „Ueber die Motive, die Husserl zum Idealismus geführt haben”, tekst dla Farbera (tylko część polskiego);

12. To samo (11), tekst czytany w Amsterdamie 1969;

13. Notatki do odczytu w Amsterdamie 1969, „Vom Erkenntnis”;

64. Wspomnienia;

65. Protokoły posiedzeń czwartkowych, oryginały, Lwów 1934/35; 
66. Odpisy protokołów czwartkowych posiedzeń lwowskich;

67. Oslo, Wykład o fenomenologii, magnetofon, niepoprawiony;

68. Oslo, Wykład o fenomenologii, magnetofon, poprawiony, posłany do druku;

69. Oslo, „Zehn Vorlesungen über Huserls Phänomenologie”, tekst ostateczny (odpis);

70. Oslo, "Zehn Vorlesungen über Husserls Phänomenologie”, drugi egzemplarz(?);

71. Oslo, „Einführung in die Theorie der Kunst und die damit verbundenen aesthetischen Probleme", magnetofon, niepoprawiony;

72. „Vom Erkennen”, pierwotny oryginał niemiecki, niepoprawiony;

73. Notatki do wykładów w U.J.K. (kilkanaście);

74. Różne:

1. „Z rozważań nad wartościami moralnymi” (wykład z etyki, 1952);

2. „Husserl «Formale und transzendentale Logik»", recenzja dla "Kant-Studien", egzemplarz wysłany do Lieberta;

3. Recenzja pracy doktorskiej Pytlaka;

4. „Bericht über meine Studien zur Aesthetik”;

5. „Über die Motive, die Husserl...”, (egzemplarz, z którego czytałem w Amsterdamie);

6. „Künstlerische Funktionen der Sprache” (dla „Die Sprachkunst”);

75. „Phänomenologische Aesthetik" - „O estetyce fenomenologicznej”, także magnetofon;

76.

a) „Wspomnienia z Getyngi”;

b) „Sprawozdanie z działalności w Uniwersytecie Jagielońskim”;

c) „Künstlerische Funktionen der Sprache” oraz korekta;

d) „Über die Motive, die Husserl zu einem tranzendentalen Idealismus brachten" (tekst czytany w Amsterdamie);

e) „Über die Motive, die Husserl zum tranzendentalen Idealismus geführt haben" oraz kopia, tekst wysłany do księgi pam. dla Farbera;

f) „O przyszłości nauki polskiej”, pisane we Lwowie w latach 30-ych; 77.

g) Notatki do dwóch odczytów w Poznaniu, 1945;

a) „Poznanie ejdetyczne u Husserla a Kantowskie a priori”, magnetofon;

b) „Poznanie ejdetyczne u Husserla a Kantowskie a priori”, magnetofon II(?);

c) „O pojęciu istoty u Husserla” (magnetofon) wszędzie wraz z dyskusją;

d) Kopie tych maszynopisów (a,b,c);

e) Notatki do powyższych odczytów oraz wypisy z Husserla; 
78. „Bemerkungen zu den «Cartesianischen Meditationen»”, pierwotny oryginał wysłany do Louvain 1949(?), Kopie tych „Bemerkungen” w 2 egzemplarzach;

79. „Co jest nowego w ostatniej książce E. Husserla”, odczyt w PTF, magnetofon wraz z dyskusją, odpis poprzedniego oraz notatki podręczne do odczytu;

[Dalej zapis Gierulanki:]

80. Wykład z filozofii nowoczesnej: recepcja Kanta (U.J. 1966) - notatki odręczne;

81. „Intuition und Intellekt bei H. Bergson” (2 zeszyty rękopisu);

82. „O pytaniach esencjalnych” (rękopis);

83. Tłumaczenia z niemieckiego: Husserl, Scheler... (rękopiśmienne notatki z 1922 r.);

84. Notatki do odczytów;

85. Wypisy z różnych autorów (z 1915 r.);

86. Protokoły Sekcji Estetyki, magnetofon.

Z maszynopisu Autora (do 79 włącznie) przepisała D. Gierulanka, 11 X $1970 \mathrm{r}$. 